\title{
PENGARUH MODEL DISCOVERY LEARNING BERBANTUAN MEDIA PHET TERHADAP HASIL BELAJAR SISWA
}

\author{
Devi Permata Sari dan Mariati P Simanjuntak \\ Jurusan Fisika FMIPA Universitas Negeri Medan \\ Jalan Willem Iskandar Pasar V Medan, Sumatera Utara \\ devipermatasari0211@gmail.com
}

\begin{abstract}
ABSTRAK
Penelitian ini bertujuan untuk mengetahui pengaruh penerapan model discovery learning berbantuan media PhET terhadap hasil belajar siswa pada materi fluida statis di kelas X semester II SMA Negeri 5 Binjai T.P. 2014/2015. Jenis penelitian ini adalah quasi experiment dengan desain control group pretest-posttest. Pengambilan sampel dilakukan dengan cara cluster random sampling dengan mengambil dua kelas dari enam kelas yaitu kelas X-1 sebagai kelas eksperimen yang berjumlah 38 orang dan kelas X-3 sebagai kelas kontrol yang berjumlah 37 orang. Instrumen yang digunakan berupa tes hasil belajar dalam aspek pengetahuan berbentuk pilihan berganda yang terdiri dari 20 soal yang sudah divalidasi dan lembar observasi untuk mengukur aktivitas, sikap dan keterampilan. Berdasarkan hasil penelitian di kelas eksperimen diperoleh rata-rata persentase perkembangan aktivitas, sikap dan keterampilan masing-masing dalam kategori baik sedangkan di kelas kontrol rata-rata persentase perkembangan sikap termasuk dalam kategori cukup baik. Berdasarkan hasil uji hipotesis menggunakan uji beda (uji-t) diperoleh ada pengaruh yang signifikan penerapan model learning berbantuan media PhET terhadap hasil belajar siswa pada materi fluida statis di kelas $\mathrm{X}$ semester II SMA Negeri 5 Binjai T.P. 2014/2015.
\end{abstract}

Kata kunci : model discovery learning, hasil belajar, aktivitas, PhET.

\section{ABSTRACT}

This research aims to know the effect of discovery learning through phet media on student learning outcome at static fluid topic in $X$ grade second semester student SMA Negeri 5 Binjai Academic Year 2014/2015. This experiment used quasi experiment type with pretest-posttest control group design. Sample was taken using technique of cluster random sampling by taking two classes of six classes, namely X-1 consisting of 38 persons as experiment class and X-3 consisting of 37 persons as control class. The data of learning outcomes in cognitive aspect is taken by using instrument test in form of multiple choice consisting 20 questions which has been tested for the validity and observation sheet for measuring the activity, affective and skill. Based on research result in the experiment class gained the average percentage of development activities, affective, and each skill included very good categories, while in the control class the average precentage of development affective included good enough categories. From the hypothesis test result by using $t$ test gained there is significant effect of implementing of discovery learning through PhET media on student learning outcome at static fluid topic in $X$ grade second semester student SMA Negeri 5 Binjai Academic Year 2014/2015. 
Keywords: model of discovery learning, learning outcomes, activities, PhET

\section{PENDAHULUAN}

Pendidikan merupakan peran yang sangat strategis dalam rangka menghasilkan sumber daya manusia (SDM) Indonesia seutuhnya, baik sebagai individu maupun sebagai anggota masyarakat. Istilah pendidikan berarti bimbingan atau pertolongan yang diberikan dengan sengaja oleh orang dewasa agar ia menjadi dewasa. Dewasa di sini maksudnya adalah dapat bertanggung-jawab terhadap diri sendiri secara biologis, psikologis, pedagogik dan sosiologis (Uhbiyati dan Ahmad, 2003). Salah satu permasalahan yang dihadapi oleh bangsa Indonesia adalah masih rendahnya kualitas pendidikan pada setiap jenjang Rendahnya pendidikan Indonesia dapat dilihat dari rendahnya hasil belajar siswa dalam berbagai mata pelajaran. Salah satu mata pelajaran yang memiliki nilai rendah adalah fisika.

Kenyataan ini sesuai dengan hasil observasi yang dilakukan oleh peneliti di SMA Negeri 5 Binjai, dengan memberikan daftar pertanyaan kepada 36 siswa, bahwa $22 \%$ siswa mengatakan tidak meyukai pelajaran fisika, $33 \%$ siswa mengatakan fisika sulit, $83 \%$ siswa mengatakan guru selalu berceramah pada saat pembelajaran fisika, 19\% siswa mengatakan guru tidak membuat percobaan atau eksperimen ketika pelajaran fisika dan $31 \%$ siswa mengatakan guru membuat soal tidak berdasarkan permasalahan kehidupan sehari-hari. Data di atas sejalan dengan kurang memuaskannya hasil belajar yang diperoleh siswa di kelas tersebut, hanya $22 \%$ siswa yang lulus Ujian Tengah Semester T.A. 2014/2015 yang mendapatkan nilai di bawah KKM. Diperoleh data hasil belajar fisika siswa yang pada umumnya masih rendah yaitu rata-rata 50, sedangkan Kriteria Ketuntasan Minimal (KKM) yang akan dicapai adalah 70 kalau dalam kurikulum 2013 sama dengan 2,66 atau B-.

Rendahnya hasil belajar siswa juga disebabkan karena guru selalu menerapkan metode belajar yang tidak bervariasi yaitu memakai pembelajaran konvensional yaitu metode ceramah dalam menyampaikan materi dan penugasan, meskipun kurikulum sudah berganti menjadi kurikulum 2013 dengan pendekatan saintifik, namun guru selalu memakai pola pengajaran yang sama yaitu guru sebagai pusat segalanya (teacher centered learning) sehingga menimbulkan kejenuhan pada diri siswa.

Selain itu juga hasil belajar fisika rendah disebabkan oleh faktor yang terdapat di dalam diri siswa, seperti sikap siswa terhadap pelajaran fisika, dimana mereka beranggapan bahwa pelajaran fisika sulit karena penuh dengan rumus-rumus yang membingungkan serta kurang menyentuh kehidupan sehari-hari, sehingga siswa tidak menyukai pelajaran fisika.

Selain itu, selama melakukan proses pembelajaran guru tidak menggunakan media pembelajaran sebagai pendukung dalam pembelajaran fisika seperti simulasi percobaan pada materi fisika yang diajarkan yaitu fuida statis, guru hanya menekankan pada berjalannya silabus agar siswa tidak ketinggalan pelajaran tanpa memperhatikan apakah siswa mengerti atau tidak pelajaran yang disampaikan. Siswa tidak dituntut untuk menemukan sendiri konsepnya, guru selalu aktif memberikan penjelasan materi tanpa memberikan bantuan media simulasi yang dapat membuat siswa mudah dalam menerima pembelajaran fisika dan guru tidak mengajak siswa untuk melakukan eksperimen. Penggunaan fasilitas sekolah seperti laboratorium dan infokus yang kurang maksimal dalam menunjang proses pembelajaran. Sistem pembelajaran ini mengakibatkan siswa malas dan tidak tertarik untuk belajar fisika.

Salah satu cara yang dapat digunakan untuk mengatasi masalah di atas adalah dengan menggunakan model pembelajaran berbantuan media yang berpusat pada siswa (student centered learning) yaitu salah satunya dengan model discovery learning berbantuan media Physic Education and Technology (PhET). Aktifnya siswa dalam 
pembelajaran maka diharapkan pembelajaran akan lebih bermakna karena siswa secara langsung diajak untuk mengkonstruksi pengetahuannya dan dengan siswa menemukan sendiri konsepnya maka materi pelajaran fisika akan lebih lama untuk diingat oleh siswa.

Menurut Hosnan (2014) model discovery learning adalah suatu model pembelajaran penemuan, siswa didorong untuk belajar sebagian besar melalui keterlibatan aktif mereka sendiri dengan konsep-konsep, prinsip-prinsip dan guru mendorong siswa untuk memiliki pengalaman melakukan percobaan yang memungkinkan mereka menemukan prinsip-prinsip untuk diri mereka sendiri. Kelebihan dari model discovery learning adalah dapat membuat pelajaran fisika lebih mudah dan kreatif karena pada model ini siswa dituntut untuk menemukan atau membuktikan sebuah konsep yaitu melalui praktikum yang membuat rasa ingin tahu siswa dalam menemukan sebuah konsep pada percobaan praktikum di sekolah.

Model discovery learning sangat efektif untuk diimplementasikan pada proses belajar mengajar di dalam kelas terutama pada kegiatan eksperimen atau percobaan sains di laboratorium. Dalam kegiatan eksperimen model discovery learning dapat melatih siswa untuk belajar aktif menemukan pengetahuan sendiri dan dapat menambah pengetahuan dan keterampilan siswa secara simultan. Sehingga dengan megimplementasikan model discovery learning ini siswa dapat dengan cepat menemukan sebuah konsep dan mempermudah guru dalam kegiatan belajar mengajar (Dahar, 2011).

Menurut (Sutman, 2010: 1) "This interaction appears to be particularly efective for helping students construct understanding and intuition for abstract and unfamiliar quantum phenomena." Simulasi PhET sangat efektif untuk membantu siswa dalam membangun pemahaman dan intuisi untuk fenomena yang bersifat abstrak. Simulasi ini tepat digunakan dalam materi fluida statis dikarenakan sifat materi yang bersifat abstrak. Manfaat dari simulasi PhET yang telah diuji dapat diuraikan sebagai berikut; (1) dapat dijadikan suatu pendekatan pembelajaran yang membutuhkan keterlibatan dan interaksi dengan siswa; (2) memberikan feedback yang dinamis; (3) mendidika siswa agar memiliki pola berfikir kontruktivisme, dimana siswa dapat menggabungkan pengetahuan awal dengan temuan-temuan virtual dari simulasi yang dijalankan; (4) membuat pembelajaran lebih menarik karena sisa dapat belajar sekaligus bermain pada simulasi tersebut; (5) menvisualisasi konsep-konsep fisika dalam bentuk model. Seperti electron, photon, molekul dll (The PhET Team, 2011)

Adapun yang menjadi tujuan penelitian untuk mengetahui pengaruh penerapan model discovery learning berbantuan media PhET terhadap hasil belajar siswa pada materi fluida statis di kelas X semester II SMA Negeri 5 Binjai T.P. 2014/2015 dan menganalisis peningkatan aktivitas belajar siswa selama proses belajar mengajar dengan menggunakan model discovery learning.

\section{METODE PENELITIAN}

Penelitian ini dilaksanakan di SMA Negeri 5 Binjai. Pelaksanaannya dilakukan pada siswa kelas $\mathrm{X}$ semester II tahun pelajaran 2014/2015. Populasi dalam penelitian ini adalah seluruh siswa kelas $\mathrm{X}$ SMA Negeri 5 Binjai Tahun Pembelajaran 2014/2015 yang terdiri dari 6 kelas. Sampel penelitian dipilih dengan menggunakan teknik penarikan sampel kelas (random sampling) dimana setiap kelas memiliki kesempatan yang sama untuk menjadi sampel penelitian, sampel diambil dari populasi secara acak yaitu sebanyak dua kelas. Satu kelas dijadikan sebagai kelas eksperimen yaitu kelas X-1 yang diterapkan model discovery learning berbantuan media phET dan satu kelas lagi dijadikan sebagai kelas kontrol yaitu kelas X-3 yang diterapkan pembelajaran konvensional. Jenis penelitian ini adalah quasi eksperimen, yaitu penelitian yang bertujuan 
untuk mengetahui ada tidaknya pengaruh atau akibat dari sesuatu yang ditimbulkan pada subjek yaitu siswa. Desain penelitian yang digunakan adalah desain control group pretest-posttest. Desain penelitian ini ditunjukkan pada Tabel 1.

Tabel 1 Desain Penelitian control group

\begin{tabular}{|l|l|l|l|}
\multicolumn{5}{c|}{ pretest-posttest } \\
\hline Kelas & Pretes & $\begin{array}{l}\text { Perlaku } \\
\text { an }\end{array}$ & $\begin{array}{l}\text { Post } \\
\text { es }\end{array}$ \\
\hline $\begin{array}{l}\text { Eksperi } \\
\text { men }\end{array}$ & $T_{1}$ & $X_{1}$ & $T_{2}$ \\
\hline Kontrol & $T_{1}$ & $X_{2}$ & $T_{2}$ \\
\hline
\end{tabular}

Keterangan:

$T_{1} \quad=$ pretes

$T_{2}=$ postes

$X_{1}=$ model discovery learning berbantuan media phET

$X_{2}=$ pembelajaran konvensional.

Sebelum dilakukan pretes terlebih dahulu dilakukannya validitas ramalan di SMA N 1 Binjai yang bertujuan untuk mengetahui validitas, reliabilitas, tingkat kesukaran dan daya beda soal. Setelah dilakukannya pretes pada kedua kelas maka hasil pretes tersebut diuji kesamaannya dengan menggunakan uji hipotesis dua pihak menggunakan uji $t$ yaitu uji kesamaan rata-rata pretes dengan syarat terdiri dari uji normalitas dan uji homogenitas. Sedangkan setelah postes dilakukan, maka hasil postes dari kelas eksperimen dan kelas kontrol akan diuji kesamaannya dengan menggunakan uji hipotesis satu pihak menggunakan uji $t$ yaitu uji kesamaan ratarata postes, yang terdiri dari uji normalitas dan uji homogenitas.

\section{HASIL DAN PEMBAHASAN}

Setelah dilakukannya uji coba instrumen tes diketahui bahwa 20 soal dinyatakan valid dan 10 soal dinyatakan tidak valid, reliabilitas tes sebesar 0,827, taraf kesukaran berbeda yaitu 2 soal mudah, 22 soal sedang dan 6 soal sukar dan daya beda yang berbeda-beda, yaitu 8 soal dalam kriteria baik, 12 soal dalam kriteria cukup baik dan 10 soal dalam kriteria jelek. Hasil pretes kedua kelas secara rinci dapat ditunjukkan pada Gambar 1 dan hasil postes kedua kelas secara rinci dapat ditunjukkan pada Gambar 2.

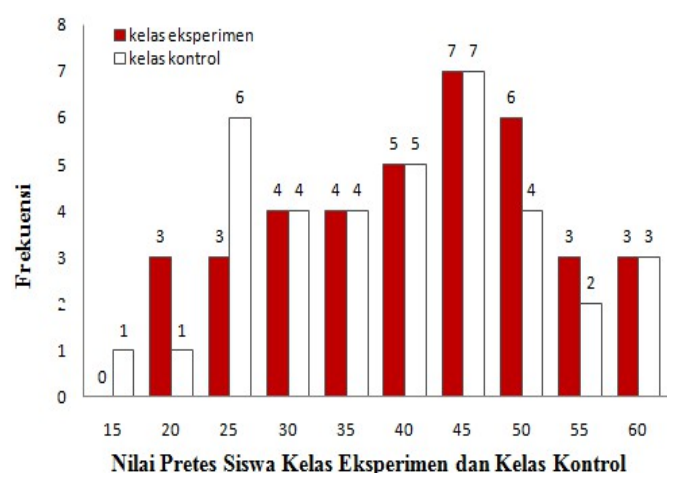

Gambar 2. Nilai Pretes Siswa Kelas

Eksperimen dan Kelas Kontrol

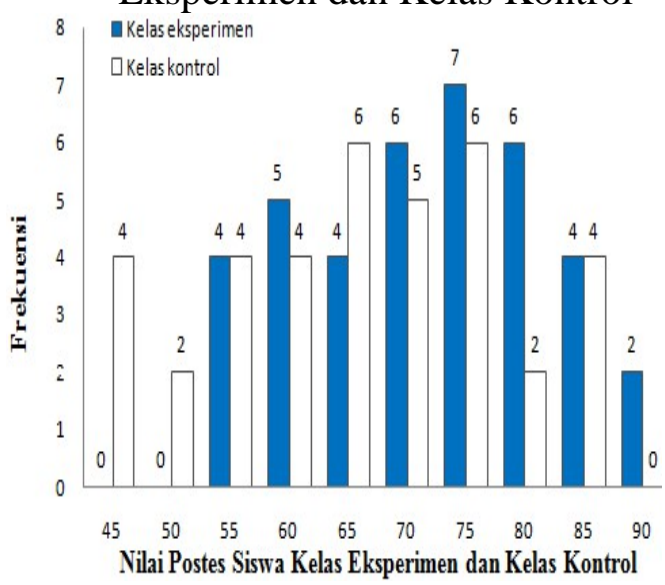

\section{Gambar 3. Nilai Postes Siswa Kelas Eksperimen dan Kelas Kontrol}

Uji normalitas data pretes dan postes kelas eksperimen dan kelas kontrol menggunakan uji Lilliefors. Hasil uji normalitas data pretes dan postes kedua kelas ditunjukkan dalam Tabel 2 dan Tabel 3.

Tabel 2 Uji Normalitas Data Pretes

\begin{tabular}{|l|l|l|l|}
\hline $\begin{array}{l}\text { Data } \\
\text { Pretes }\end{array}$ & $\mathbf{L}_{\text {hitung }}$ & $\mathbf{L}_{\text {tabel }}$ & $\begin{array}{l}\text { Kesimpul } \\
\text { an }\end{array}$ \\
\hline $\begin{array}{l}\text { Kelas } \\
\text { Eksperime } \\
\mathrm{n}\end{array}$ & $\begin{array}{l}0,143 \\
0\end{array}$ & $\begin{array}{l}0,089 \\
5\end{array}$ & normal \\
\hline $\begin{array}{c}\text { Kelas } \\
\text { Kontrol }\end{array}$ & $\begin{array}{l}0,103 \\
7\end{array}$ & $\begin{array}{l}0,145 \\
0\end{array}$ & normal \\
\hline
\end{tabular}


Tabel 3 Uji Normalitas Data Postes

\begin{tabular}{|l|l|l|l|}
\hline $\begin{array}{l}\text { Data } \\
\text { Pretes }\end{array}$ & $\mathbf{L}_{\text {hitung }}$ & $\mathbf{L}_{\text {tabel }}$ & $\begin{array}{l}\text { Kesimpul } \\
\text { an }\end{array}$ \\
\hline $\begin{array}{l}\text { Kelas } \\
\text { Eksperime } \\
\mathrm{n}\end{array}$ & $\begin{array}{l}0,109 \\
7\end{array}$ & $\begin{array}{l}0,143 \\
0\end{array}$ & normal \\
\hline $\begin{array}{c}\text { Kelas } \\
\text { Kontrol }\end{array}$ & $\begin{array}{l}0,078 \\
0\end{array}$ & $\begin{array}{l}0,145 \\
0\end{array}$ & normal \\
\hline
\end{tabular}

Uji homogenitas menggunakan uji $\mathrm{F}$ dari data pretes dan postes kelas eksperimen dan kelas kontrol. Ternyata untuk data pretes $F_{\text {hitung }}<\mathrm{F}_{\text {tabel }}(1,044<$ 1,738) dan untuk data postes $F_{\text {hitung }}<F_{\text {tabel }}$ $(1,411<1,738)$. Ini berarti varians kedua sampel homogen pada taraf signifikan $\alpha=$ 0,10 . Uji hipotesis menggunakan uji $t$, dimaksudkan untuk melihat perbedaan hasil belajar di kelas eksperimen dan kelas kontrol akibat pengaruh model discovery learning berbantuan media phET. Syarat uji $t$ ini adalah data harus berdistribusi normal dan sampel harus berasal dari populasi yang homogen. Melihat kedua syarat tersebut telah terpenuhi, berikut ini disajikan ringkasan perhitungan dengan uji t, dengan $\alpha=0,05$ dari data postes. Dari hasil perhitungan diperoleh $t_{\text {hitung }}=2,34$ sedangkan $t_{\text {tabel }}$ dengan $\alpha=0,05$ adalah 1,669. Dapat disimpulkan bahwa terdapat pengaruh model discovery learning berbantuan media phET terhadap hasil belajar siswa pada materi fluida statis kelas $\mathrm{X}$ semester II SMA N 5 Binjai.

Indikator aktivitas yang dinilai adalah memberikan jawaban, memberikan pertanyaan, melakukan diskusi dan menjawab soal. Hasil perkembangan aktivitas belajar siswa di kelas eksperimen dapat ditunjukkan pada Gambar 3.

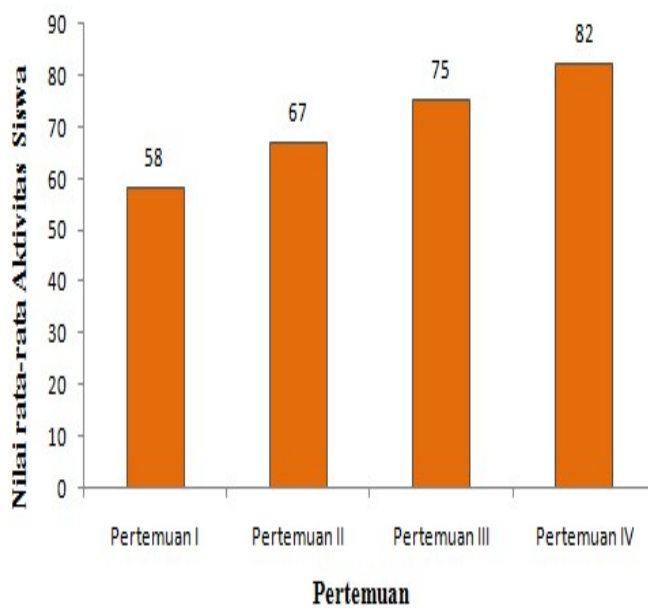

Gambar 3. Persentase Aktivitas Siswa Kelas Eksperimen

Penilaian sikap yang dinilai adalah disiplin, tanggung jawab, jujur, teliti, kreatif dan peduli. Sikap yang ditunjukkan siswa menunjukkan perubahan yang baik. Perkembangan hasil belajar dalam aspek sikap antara kedua kelas ditunjukkan pada Gambar 4.

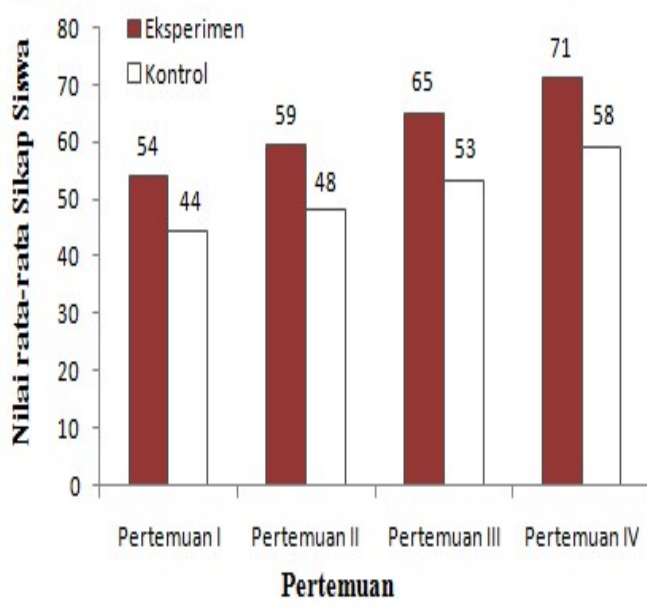

Gambar 4. Persentase Sikap Kedua Kelas

Kriteria penilaian sikap kelas eksperimen pada pertemuan pertama hingga kedua dinyatakan cukup baik dan pada pertemuan ketiga hingga keempat adalah baik, sedangkan pada kelas kontrol pada pertemuan pertama hingga keempat termasuk dalam kriteria cukup baik. Penilaian keterampilan yang dinilai adalah merencanakan percobaan, merangkai alat, melakukan pengamatan, data yang diperoleh dan menyimpulkan. Hasil 
perkembangan keterampilan siswa dapat ditunjukkan pada Gambar 5.

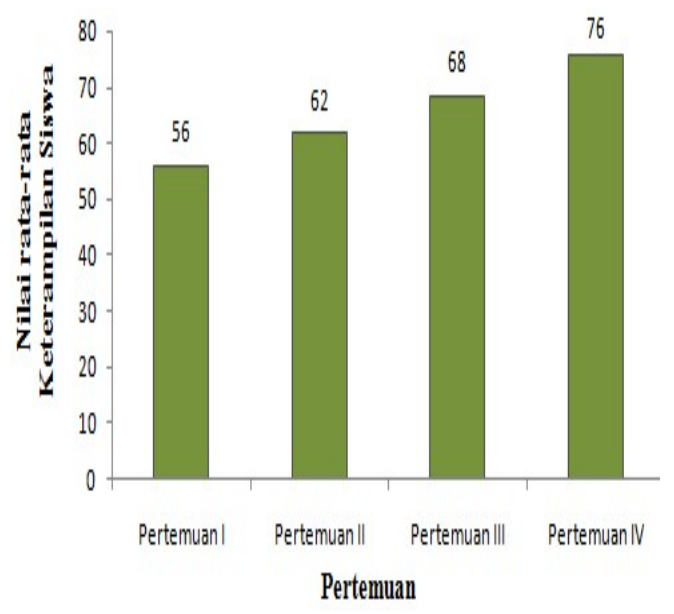

Gambar 5. Persentase Penilaian Sikap Kelas Eksperimen

Hasil penelitian menunjukkan bahwa ada pengaruh model discovery learning berbantuan media PhET terhadap hasil belajar siswa pada materi fluida statisr di Kelas X Semester II SMA N 5 Binjai. Hal ini dapat dilihat dengan adanya perbedaan hasil belajar dan hasil observasi aktivitas antara kelas eksperimen dengan kelas kontrol. Pengaruh model discovery learning memberikan perbedaan terhadap hasil belajar pada aspek pengetahuan dikarenakan model discovery learning mempunyai enam tahap atau fase pembelajaran yang membuat pengetahuan siswa menjadi lebih baik dan meningkat. Selama penelitian berlangsung pada pertemuan pertama hingga pertemuan keempat diperoleh bahwa pada tahap 1 yaitu memberikan stimulus atau pemberian rangsangan kepada siswa, pada pertemuan pertama siswa masih terlihat bingung dang kurang aktif untuk memberikan respon pembelajaran yang diberika peneliti, masih banyak yang diam, tetapi pada pertemuan kedua dan ketiga siswa sudah mulai memberikan tanggapan atau respon dengan satu dan dua orang yang memberikan argumen ataupun pertanyaan hingga pada pertemuan keempat sudah banyak siswa yang berargumen atau memberikan pertanyaan dengan stimulus pembelajaran yang diberikan peneliti kepada siswa.

Tahap 2, 3 dan 4 yaitu mengidentifikasi masalah, mengumpulkan data dan pengolahan data dimana pada tahap ini siswa melakukan eksperimen, pada pertemuan pertama terjadi keributan sesama siswa karena pembagian kelompok yang tidak biasa dilakukan pada pembelajaran sehingga peneliti sulit untuk mengatur, kemudian siswa bingung dan berkomentar dengan masalah yang diberikan oleh peneliti, karena mereka tidak pernah mendapatkan masalah fisika dalam pembelajaran sebelumnya sehingga peneliti menjelaskan berulang kembali mengenai masalah yang disajikan hingga mereka paham apa yang dimaksud pada masalah tersebut, tetapi setelah dilihat dari pertemuan kedua dan ketiga pembagian kelompok semakin kondusif hingga siswa semakin paham mengenai masalah yang disajikan dan pada pertemuan keempat kegiatan eksperimen berjalan dengan baik dan siswa tidak lagi bingung dan komentar mengenai masalah dan dapat mengolah data yang didapat.

Tahap 5 dan 6 yaitu pembuktian dan menarik kesimpulan, pada pertemuan pertama siswa belum bisa untuk menghubungkan penemuan konsep yang didapat pada praktikum dengan konsep yang ada dibuku referensi sehingga pada membuat kesimpulan tidak sesuai masalah yang diberikan, sehingga peneliti kembali menjelaskan kepada siswa agar kesimpulan yang didapat harus sesuai dengan masalah yang diberikan peneliti dan mampu menghubungkan konsep yang ditemukan pada eksperimen dengan konsep yang ada pada buku ataupun referensi lainnya, kemudian pada pertemuan kedua hingga keempat siswa sudah semakin paham dan kesimpulan yang didapat sesuai dengan yang diharapkan.

Berdasarkan uraian di atas dapat disimpulkan bahwa model discovery learning dapat meningkatkan hasil belajar dan aktivitas siswa dalam proses 
pembelajarn fisika. Hal ini didukung oleh Hosnan (2014) model discovery learning adalah suatu model pembelajaran untuk mengembangkan cara belajar siswa aktif dengan menemukan sendiri, menyelidiki sendiri, maka hasil yang diperoleh akan setia dan tahan lama dalam ingatan dan tidak akan mudah dilupakan siswa. Dengan belajar penemuan, siswa juga bisa belajar analisis dan mencoba memecahkan sendiri masalah fisika yang dihadapi. Karakteristik model discovery learning yang menuntut siswa untuk melakukan sebuah penemuan terhadap suatu konsep melalui kegiatan eksperimen, sehingga jika mereka menemukan dan mengalaminya sendiri akan jauh lebih lama mengingat dan lebih baik pemahamannya, karena pemahamannya yang lebih inilah membuat siswa memecahkan masalah fisika dengan lebih baik. Kunci keberhasilan pengajaran discovery adalah mengerti bahwa tingkat keterampilan dan tanggung jawab bisa lebih meningkat dalam proses belajar.

Selain model discovery learning yang membuat aktivitas siswa menjadi lebih aktif juga karena didukung oleh bantuan media yaitu media simulasi PhET. Simulasi PhET sangat efektif untuk membantu siswa dalam membangun pemahaman dan intuisi untuk fenomena yang bersifat abstrak. Hal ini juga dapat disebabkan ilustrasi dan visualisasi yang diberikan memotivasi siswa untuk tetap belajar. Selain itu, percobaan yang dilakukan siswa ketika melaksanakan praktikum dapat dibuktikan kebenaran konsepnya dengan menggunakan simulasi PhET.

Hal ini diperkuat dengan adanya perkembangan aktivitas siswa di kelas eksperimen. Aktivitas siswa pada kelas eksperimen setiap pertemuan mengalami perkembangan yang baik dari pertemuan I sampai pertemuan IV. Nilai rata-rata pertemuan I yaitu 58, pertemuan II nilai rata-rata aktivitas siswa yaitu 67 , peretemuan III nilai rata-rata aktivitas siswa yaitu 75 dan pertemuan IV nilai rata-rata aktivitas siswa yaitu 82 , sehingga nilai rata- rata aktivitas siswa selama pembelajaran di kelas eksperimen adalah 71 dengan kriteria aktif.

Penilaian sikap siswa pada kelas eksperimen juga meningkat setiap pertemuannya. Rata-rata persentase penilaian sikap kelas eksperimen dengan menggunakan model discovery learning berbatuan media $\mathrm{PhET}$ adalah 62 yang termasuk dalam kategori baik sedangkan menggunakan pembelajaran konvensional rata-rata persentase adalah 51 yang termasuk dalam kategori cukup baik. Selanjutnya, untuk penilaian keterampilan siswa pada kelas eksperimen juga mengalami peningkatan di setiap pertemuannya. Rata-rata persentase keterampilan siswa di kelas eksperimen dengan menggunakan model discovery learning berbantuan media PhET adalah 66 yang termasuk dalam kriteria baik. Kelas kontrol tidak dilakukan penilaian keterampilan, yang dinilai hanya observasi sikap dan hasil belajar pengetahuan, karena pada kelas kontrol tidak ada melakukan eksperimen maupun demonstrasi yang dilakukan oleh guru.

Berdasarkan hasil penelitian yang dilakukan oleh Isnaning dan Bimo (2013), Indarti, dkk., (2013); dan Balim (2009), diperoleh bahwa ada perbedaan hasil belajar siswa yang signifikan antara kelas yang menggunakan model discovery learning dan pembelajaran konvensional. Pembelajaran model discovery learning meningkatkan keterampilan siswa dan hasil belajar siswa. Model discovery learning dapat meningkatkan pemahaman konsep siswa. Siswa dapat mengkaitkan kesamaan konsep yang telah mereka pelajari guna menemukan konsep baru tentang materi yang sedang dipelajari. Sejak awal, siswa yang belajar dengan model discovery learning telah terlatih menemukan konsep baru untuk menyelesaikan masalah fisika.

Beberapa penelitian terdahulu juga menunjukkan sejumlah kelebihan media simulasi PhET dalam pembelajaran fisika. Menurut Fienkelstein dan Noah, (2008), menemukan bahwa penggunaan simulasi 
PhET efektif dalam pembelajaran konsep terbukti membantu siswa dalam memahami konsep abstrak dan proses mikroskopik yang tidak dapat diobservasi secara langsung. Penelitian ini juga menunjukkan bahwa simulasi yang digunakan efektif dalam membantu siswa dalam pencapaian proses belajar di dalam kelas.

Penggunaan model discovery learning berbantuan media PhET dapat meningkatkan hasil belajar dan aktivitas siswa, namun masih ada kendala yang dihadapi selama pembelajaran. Salah satu kendala yang terjadi adalah ketika mengorganisasikan siswa dalam kelompok, menggunakan waktu yang cukup lama oleh karena siswa di kelas ini belum terbiasa dalam pembentukan kelompok. Sebelumnya ada kelompok belajar, namun tugas kelompok yang dikerjakan bukan di sekolah, melainkan di rumah. Rasa malu dan keragu-raguan dalam pengambilan kesimpulan masih tertanam pada diri siswa, sehingga siswa mengalami kesulitan dalam membuat kesimpulan hasil kerja kelompoknya. Kemudian fasilitas sekolah yaitu terbatasnya infokus yang membuat kurang mendukung dalam keberhasilan proses belajar mengajar dan pembagian kelompok yang terlalu banyak sehingga terdapat siswa yang pasif dalam praktikum.

\section{KESIMPULAN DAN SARAN \\ Kesimpulan}

Kesimpulan yang diperoleh berdasarkan hasil penelitian adalah hasil belajar siswa dalam aspek pengetahuan di kelas eksperimen yang dengan model discovery learning berbantuan media PhET dengan nilai rata-rata adalah 71,71. Kemudian hasil belajar pada penilaian sikap di kelas eksperimen pada setiap pertemuanya mengalami perkembangan dengan rata-rata persentasenya adalah 62,35 dengan kategori baik. Selanjutnya hasil belajar pada penilaian keterampilan di kelas eksperimen pada setiap pertemuanya juga mengalami perkembangan dengan rata-rata persentasenya adalah 65,48 dengan kriteria baik. Hasil belajar siswa dalam aspek pengetahuan di kelas kontrol dengan menggunakan pembelajaran konvensional dengan nilai rata-rata adalah 65,67. Kemudian hasil belajar pada penilaian sikap di kelas kontrol pada setiap pertemuanya mengalami perkembangan dengan rata-rata persentasenya adalah 51,16 dengan kategori cukup baik. Aktivitas belajar siswa selama mengikuti pembelajaran dengan menggunakan model pembelajaran discovery learning berbantuan media PhET pada materi pokok fluida statis di kelas $X$ semester II SMA Negeri 5 Binjai T.P. 2014/2015 adalah lebih aktif dengan rata-rat persentasenya adalah 70,65 dengan kategori aktif. Berdasarkan hasil perhitungan uji $t$ diperoleh bahwa ada perbedaan karena pengaruh penggunaan model discovery learning berbantuan media PhET terhadap hasil belajar siswa pada materi pokok fluida statis di kelas X Semester II SMA Negeri 5 Binjai T.P. 2014/2015.

\section{Saran}

Saran untuk peneliti selanjutnya diharapkan agar mendapatkan hasil yang lebih baik dan memastikan bahwa sekolah memiliki sarana dan prasarana yang mendukung. Selanjutnya agar lebih memperhatikan dalam pembagian kelompok yang sebaiknya jumlah siswa dalam setiap kelompok cukup 3-4 orang.

\section{DAFTAR PUSTAKA}

Balim, A. G. (2009). The Effects of Discovery Learning on Students' Success and Inquiry Learning Skills. University Faculty of Education, Turkey.

Dahar, R. W., (2011), Teori-Teori Belajar, Erlangga. Jakarta

Fienkelstein, D. dan Noah, (2008), Developing and Researching PhET simulations for Teaching Quantum Mechanics. Journal of Applied Physics (http://www.colorado.edu/physics/ EducationIssues/papers/QMsims.p df) (09 Maret 2015) 
Hosnan, (2014), Pendekatan Saintifik dan Kontekstual dalam Pembelajaran Abad 21, Ghalia Indonesia. Bogor

Indarti, Agus S, dan Chusnana I.Y, (2013), Pengaruh Model Discovery Learning Terhadap Kemampuan Memecahkan Masalah Siswa Kelas $X$ SMAN 8 Malang, Universitas Negeri Malang. Malang

Isnaning dan Bimo, (2013), Penerapan Lembar Kegiatan Siswa (Lks) DiscoveryBerorientasi

Keterampilan Proses Sains Untuk Meningkatkan Hasil Belajar IPA, Universitas Terbuka, Semarang.

Sutman, X. F., (2010), The Science Quest Using Inquiry/Discovery to Enchance Student Learning, Jossey-Bass, Canada.

Uhbiyati N. dan Ahmadi A., (2003), Ilmu Pendidikan, Rineka Cipta. Jakarta.

The PhET Team. 2011. PhET (Intective Simulations).

http://phet.colorado.edu/in/. Maret 2015) 